\title{
Not only pond sliders: freshwater turtles in the water bodies of the Milan northern urban area (Italy)
}

\author{
Claudio Foglini
}

\begin{abstract}
Freshwater turtles represent one of the most common pets released in urban water bodies. In Europe, after the ban on the import of Trachemys scripta, other non-native turtle species now dominate the legal pet trade. Some of these species have high invasive potential, such as the well-known slider turtle, but their diffusion outside their native range is poorly known. This work summarises presence data about non-native freshwater turtles, different from slider turtles $T$. scripta, into two urban parks located at the northern boundary of the Milan outskirts (Italy, Lombardy). Turtle detections were obtained merging field surveys conducted from 2014 to 2020, with sparse pictures taken by occasional observers. The situation depicted shows, in addition to the ubiquitous spread of slider turtle subspecies and hybrids in both parks, the frequent presence of other multiple genera such as Pseudemys and Graptemys. Isolated individuals of Apalone spinifera, Graptemys ouachitensis, Mauremys sinensis, Pelomedusa subrufa and Sternotherus carinatus were also found. I also detected one Emys orbicularis, probably escaped or released.
\end{abstract}

Key words: Chinese stripe-necked turtle, Florida red-bellied cooter, false map turtle, non-native turtles, Ouachita map turtle, river cooter, urban wetlands.

Riassunto - Non solo testuggini palustri americane: testuggini d'acqua dolce nei corpi idrici dell'area urbana settentrionale di Milano (Italia).

Le testuggini palustri rappresentano alcuni degli animali da compagnia più comunemente rilasciati nelle zone umide urbane. In Europa, dopo il divieto di importazione delle sottospecie e degli ibridi di Trachemys scripta, altri generi di testuggini alloctone dominano ora il mercato legale degli animali da compagnia esotici. Alcuni di questi, analogamente alle ben note testuggini palustri americane, mostrano un elevato potenziale di invasività ma la loro distribuzione al di fuori del loro areale naturale è scarsamente indagata. Questo lavoro sintetizza i dati di presenza delle testuggini palustri alloctone, oltre a T. scripta, all'interno di due parchi urbani nell'hinterland nord di Milano (Italia, Lombardia). I dati di presenza derivano dall'unione di rilievi di campo condotti dal 2014 al 2020 con segnalazioni di osservatori occasionali. Il quadro che emerge mostra, oltre alla presenza ubiquitaria di sottospecie ed ibridi del genere Trachemys,

Via Leon Battista Alberti 8/A, 20092 Cinisello Balsamo (MI), Italia.

E-mail: clafogli@libero.it

(C) 2021 Claudio Foglini

Received for publication: 2 April 2021

Accepted for publication: 7 September 2021

Online publication: 29 October 2021 una forte presenza di altri generi di testuggini tra cui Pseudemys e Graptemys. Sono anche stati rinvenuti individui isolati di Apalone spinifera, Graptemys ouachitensis, Mauremys sinensis, Pelomedusa subrufa e Sternotherus carinatus. Inusuale è il ritrovamento di un individuo di Emys orbicularis, quasi certamente frutto di rilascio.

Parole chiave: Graptemys ouachitensis, Graptemys pseudogeografica, Mauremys sinensis, Pseudemys concinna, Pseudemys nelsoni, tartarughe alloctone, zone umide urbane.

\section{INTRODUCTION}

Artificial water bodies in urbanized landscapes are multifunctional habitats important for the conservation of many plants and animals. The lack of predators, the large availability of food and an encouraging human behaviour may create a relatively suitable and stable habitat for many alien animal and plants (van Ham et al., 2013).

Freshwater turtles represent one of the most common group of non-native species introduced in urban and suburban wetlands (Piovano \& Giacoma, 1999; Conner et al., 2005; Burgin, 2006; De Lathouder et al., 2009; Masin et al., 2014). With at least 64 widely traded species (Çicek \& Ayaz, 2015), young turtles are kept as pets, but upon growing to a large size, they are often released into the wild (Crescente et al., 2014). In Europe, the red-eared slider turtle Trachemys scripta elegans (Wied-Neuwied, 1839) was the most widely traded taxon since 1970, but after the ban of its import in 1997 (European Commission, 1997) and a further ban extended to all T. scripta subspecies (mainly T. s. scripta Thunberg in Schoepff, 1792 and T. s. troostii Holbrook, 1836) and hybrids (European Commission, 2001 and subsequent amendments; European Commission, 2014), the legal pet trade switched to different taxa (Bringsøe, 2006). Apalone, Graptemys, Kinosternon, Mauremys, Pelodiscus, Pelomedusa, Pseudemys and Sternotherus are only examples among the most traded genera, due to a cheap retail price of around 30 euros per hatchling (Masin et al., 2014). Other species are often traded, but only in dedicated fairs or with higher retail prices. Some species, such as the common snapping turtle Chelydra serpentina (L., 1758) and the Western alligator snapping turtle Macrochelys temminckii (Troost in Harlan, 1835) are banned in some EU country (i.e., Italy and Germany) being considered "dangerous species" (Masin et al., 2014). 
The aim of this work is to highlight and quantify the presence of non-native turtle species, besides the now ubiquitous Trachemys scripta, in two urban parks located in the Milan northern outskirt.

\section{MATERIALS AND METHODS}

In Northern Italy, the Po Valley lowland is a largely human landscape, with agricultural land strictly intermingled with prevalent built-up areas. The few residual natural habitats are protected by a number of protected areas, creating the Regional Ecological Network (Rete Ecologica Regionale Lombarda; Bogliani et al., 2007). The Parco Grugnotorto Villoresi and the Parco Nord Milano are two key elements of this ecological network are (Fig. 1).

The Parco Grugnotorto Villoresi (1850 ha) is a local park managed by a supra-municipal consortium (PLIS, Parco Locale di Interesse Sovracomunale): located about $10 \mathrm{~km}$ north from downtown Milan, it is mainly composed by residual agricultural landscape scattered within the urban matrix. Major wetlands consist of a former quarry converted into a naturalized lake with reedbeds and provided with recreational areas (Parco Lago Nord, Fig. 1a), and a small artificial lake in the Southeastern area (Sant'Eusebio protected area, Fig. 1b). Another characterizing element is the Villoresi channel, a waterway built in the $19^{\text {th }}$ century for irrigation. The Parco Grugnotorto Villoresi e Brianza Centrale was established in 2019 from the union of the Parco Grugnotorto Villoresi and the Parco Brianza Centrale (400 ha). The Parco Nord Milano is a peri-urban regional park (790 ha), located in the northern outskirts of Milan and created in the late 1960s on the

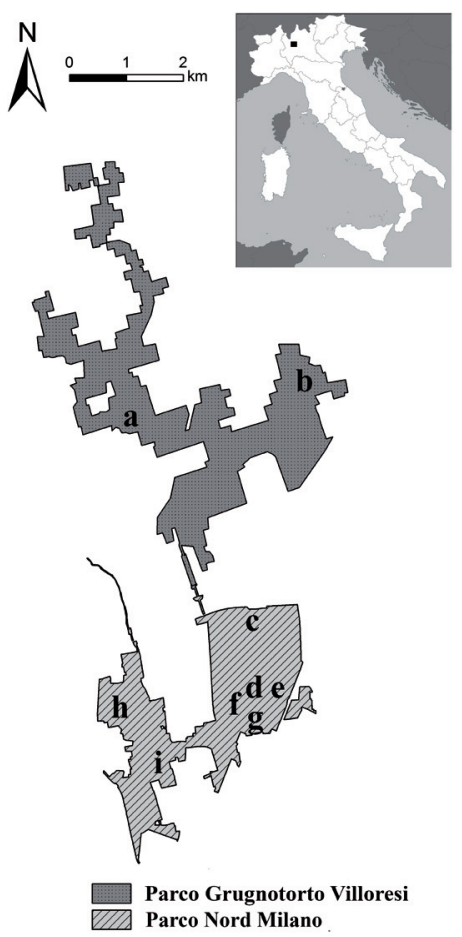

Breda brownfield. First reforestations date back to 1983; woods, meadows and lawns, wetlands and bike lanes were added during the years. The current freshwater system is composed by seven lakes, slow-flowing water ditches and few small ponds (Fig. 1c-1i). The geographical coordinates of all the surveyed wetlands are given in Table 1.

Turtle surveys were performed from spring to late summer 2014-2020, walking at slow pace along the wetlands' banks in sunny days between 11:00 AM and 03:00 PM, when turtle basking activity is greater (Cadi \& Joly, 2000). Turtles were identified in the field using binoculars (Olympus 12x50 EXPS I). When in doubt, pictures were taken using a DSLR camera (Canon 50D and 7D) with telephoto (Canon 400/5.6 L) for a more thorough successive examination. Sparse observations were also collected from the visitors and the park's staff, but considered reliable only when coupled with good quality pictures. Pictures of non-Trachemys turtles taken during a capturemarking-recapture study of 2013 (Foglini \& Salvi, 2017) were also re-examined. The checklist by Rhodin et al., 2017 was used as the main reference for identification, but since turtle species discrimination from pictures can be challenging especially for some genera, the keys by Vogt (1993) for Graptemys and by Seidel \& Ernst (1996) for Pseudemys were also used.

\section{RESULTS}

A list of the non-native turtle species found in the study area is provided in Table 2, and their distribution is shown in Fig. 2. The presence of four cooters Pseudemys sp. (Gray 1856) and 10 false map turtles Graptemys pseu-

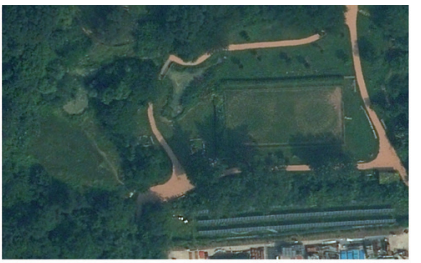

d) Educational area

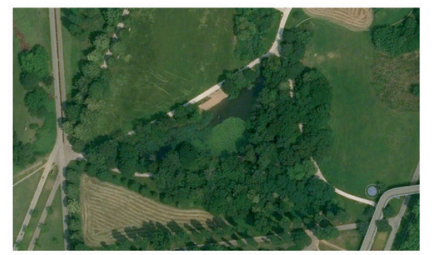

e) Suzzani Lake

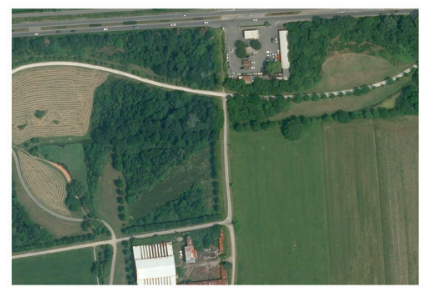

f) Bresso Lakes

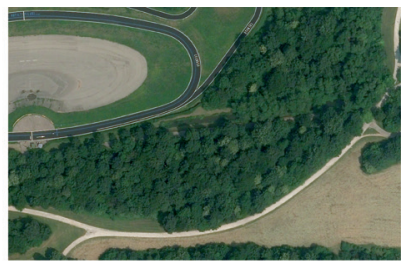

g) Breda ditch

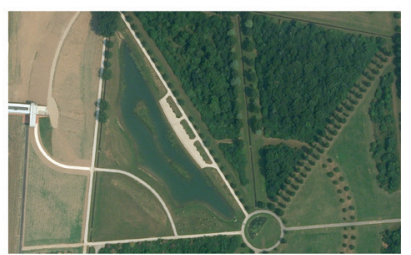

h) Bruzzano Lake

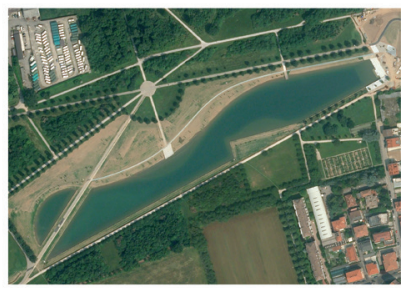

i) Niguarda Lake

Fig. 1 - Study area (Lombardy region, Northern Italy). Letters indicate each studied wetland (modified from www.d-maps.com and GeoPortale Regione Lombardia). / Area di studio (Lombardia, Italia Settentrionale). Ogni lettera identifica un'area umida indagata (modificato da https://d-maps.com/ e GeoPortale Regione Lombardia). 
Tab 1. - Geographical coordinates of each studied wetland. Name and letters as in Fig. 1. / Coordinate geografiche di ciascuna area umida indagata. Nomi e lettere come in Fig. 1.

\begin{tabular}{|l|l|l|}
\hline Wetland name & Coordinates (D.M.S.) & Fig. 1 \\
\hline Parco Lago Nord & $45^{\circ} 34^{\prime} 37.60^{\prime \prime} \mathrm{N} ; 9^{\circ} 10^{\prime} 54.00^{\prime \prime} \mathrm{E}$ & $\mathrm{a}$ \\
\hline Sant'Eusebio protected area & $45^{\circ} 34^{\prime} 31.15^{\prime \prime} \mathrm{N} ; 9^{\circ} 13^{\prime} 01.00^{\prime \prime} \mathrm{E}$ & $\mathrm{b}$ \\
\hline Cinisello Lake & $45^{\circ} 32^{\prime} 46.75^{\prime \prime} \mathrm{N} ; 9^{\circ} 12^{\prime} 20.60^{\prime \prime} \mathrm{E}$ & $\mathrm{c}$ \\
\hline Educational area & $45^{\circ} 32^{\prime} 16.60^{\prime \prime} \mathrm{N} ; 9^{\circ} 12^{\prime} 25.00^{\prime \prime} \mathrm{E}$ & $\mathrm{d}$ \\
\hline Suzzani Lake & $45^{\circ} 31^{\prime} 50.40^{\prime \prime} \mathrm{N} ; 9^{\circ} 12^{\prime} 45.25^{\prime \prime} \mathrm{E}$ & $\mathrm{e}$ \\
\hline Bresso Lakes & $45^{\circ} 31^{\prime} 54.18^{\prime \prime} \mathrm{N} ; 9^{\circ} 12^{\prime} 08.99^{\prime \prime} \mathrm{E}$ & $\mathrm{f}$ \\
\hline Breda ditch & $45^{\circ} 31^{\prime} 45.95^{\prime \prime} \mathrm{N} ; 9^{\circ} 12^{\prime} 23.00^{\prime \prime} \mathrm{E}$ & $\mathrm{g}$ \\
\hline Bruzzano Lake & $45^{\circ} 32^{\prime} 00.25^{\prime \prime} \mathrm{N} ; 9^{\circ} 10^{\prime} 29.85^{\prime \prime} \mathrm{E}$ & $\mathrm{h}$ \\
\hline Niguarda Lake & $45^{\circ} 31^{\prime} 26.85^{\prime \prime} \mathrm{N} ; 9^{\circ} 11^{\prime} 14.20^{\prime \prime} \mathrm{E}$ & $\mathrm{i}$ \\
\hline
\end{tabular}

Tab. 2 - Summary table about non-native turtle species found in the study area (in alphabetical order). The widespread T. scripta is omitted. The number of detected individuals (N) is provided for each species. Locality names and positions as in Fig. 1. / Tabella di riepilogo sulle specie di testuggini alloctone rinvenute nell'area di studio (in ordine alfabetico). Omessa l'ubiquitaria T. scripta. Per ciascuna specie è indicato il numero di individui contattati (N). Nome delle aree umide e loro posizione come in Fig. 1.

\begin{tabular}{|c|c|c|c|c|}
\hline Species & Location & Date & $\mathbf{N}^{\circ}$ & References (pictures) \\
\hline Apalone spinifera & Parco Lago Nord & 19 May 2018 & 1 & Appendix 1, Fig A11 \\
\hline Emys orbicularis & Educational area & 8 June 2016 & 1 & Ghislandi, pers. comm. (Appendix 1, Fig. A2) \\
\hline \multirow[t]{2}{*}{ Graptemys ouachitensis } & Suzzani Lake & June 2014 & 2 & Appendix 1, Fig. A1 \\
\hline & Parco Lago Nord & 7 July 2019 & 1 & Appendix 1, Fig. A10 \\
\hline \multirow{2}{*}{ Graptemys pseudogeographica } & Bresso Lakes & April-August 2013 & 6 & Foglini \& Salvi, 2017 \\
\hline & Bresso Lakes & 5 July 2018 & 1 & Gelso, pers. comm. (Appendix 1, Fig. A14a and b) \\
\hline G.p.pseudogeographica & Parco Lago Nord & $2014-2020$ & $\approx 10$ & Appendix 1, Fig. A8a \\
\hline G. p. khoni & Parco Lago Nord & $2014-2020$ & $\approx 10$ & Appendix 1, Fig. A8b and A9 \\
\hline \multirow{3}{*}{ Mauremys sinensis } & Niguarda Lake & 22 August 2020 & 1 & Gelso, pers. comm. (iNaturalist obs. $\mathrm{n}^{\circ} 57588085$ ) \\
\hline & Suzzani Lake & 1 September 2020 & 1 & Gelso, pers. comm. (iNaturalist obs. ${ }^{\circ} 58439470$ ) \\
\hline & Parco Lago Nord & 18 September 2020 & 1 & Appendix 1, Fig. A12 \\
\hline Pelomedusa subrufa & Parco Nord Milano & 27 July 2017 & 1 & Siliprandi, pers. comm. (Appendix 1, Fig. A3a and b) \\
\hline \multirow[t]{4}{*}{ Pseudemys concinna } & Suzzani Lake & April-August 2013 & 3 & Foglini \& Salvi, 2017 (See notes in Results) \\
\hline & Breda ditch & April-August 2013 & 1 & Foglini \& Salvi, 2017 (See notes in Results) \\
\hline & Parco Lago Nord & $2014-2020$ & $\approx 20$ & Appendix 1, Fig. A6b and A7b \\
\hline & Sant'Eusebio p. a. & $2014-2020$ & 2 & Appendix 1, Fig. A13 \\
\hline
\end{tabular}




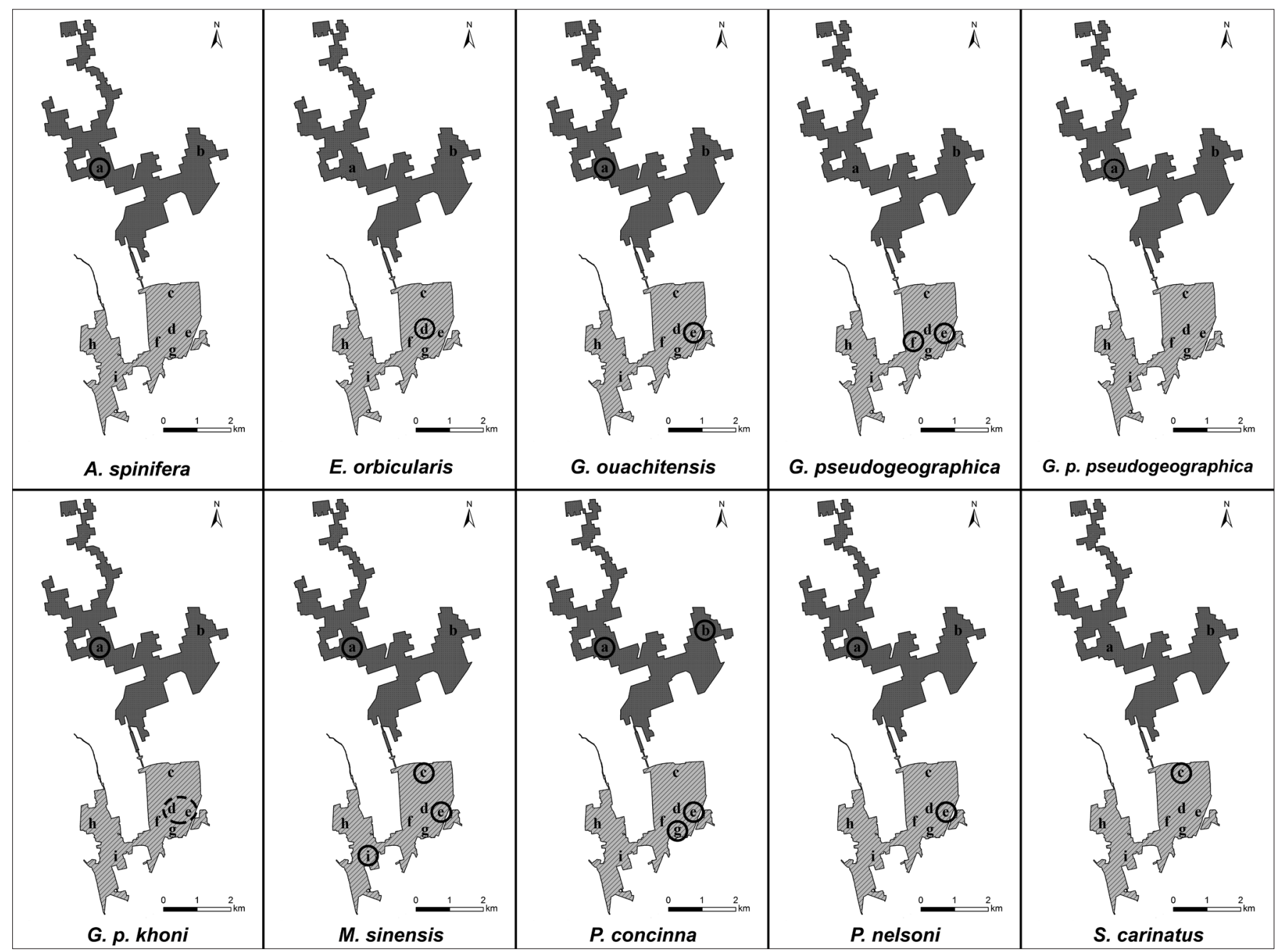

Fig. 2 - Distribution maps of the species found in the study area. Circled letters: species records; when the position is approximated, the circle is dashed. P. subrufa records are omitted because the species was recovered far from the wetlands; also T. scripta is not shown, because the species was excluded from the study. Letters indicate the wetlands as in Fig. 1 (modified from https://d-maps.com/ and GeoPortale Regione Lombardia). / Mappa di distribuzione delle specie rinvenute nell'area di studio. Lettera cerchiata: specie presente; quando la posizione è approssimativa, il cerchio è tratteggiato. Il dato per P. subrufa è omesso in quanto la specie è stata rinvenuta lontano dalle zone umide; la distribuzione di T. scripta non è indicata poiché la specie non è oggetto del presente studio. Le aree umide sono indicate da lettere secondo la nomenclatura usata in Fig. 1 (modificato da https://d-maps.com/ e GeoPortale Regione Lombardia).

dogeographica (Gray 1831) in the Parco Nord Milano, as well as the presence of a large T. scripta population, are described in Foglini \& Salvi, 2017.

After that study, in the same place other species were found: Florida red-bellied cooter Pseudemys nelsoni (Carr 1938) (two individuals, 2014), Ouachita map turtle Graptemys ouachitensis (Cagle 1953) (two individuals, June 2014; Appendix 1: Fig. A1), European pond turtle Emys orbicularis (L. 1758) (one individual, 28 June 2016: Ghislandi, pers. comm.; Appendix 1: Fig. A2; summer 2017: Gelso, pers. comm.), helmeted turtle Pelomedusa subrufa (Bonnaterre 1789) (one individual, 27 July 2017: Siliprandi, pers. comm.; Appendix 1: Figs. A3a and b), Northern false map turtle G. p. kohnii (Baur 1890) (one female, 3 July 2018: Ferri et. al., 2019), Chinese stripe-necked turtle Mauremys sinensis (Gray 1834) (one individual, 24 June 2020: Tucci, pers. comm.; Appendix 1: Figs. A4a and b), razor-backed musk turtle Sternotherus carinatus (Gray
1856) (one individual, 24 June 2020: Tucci, pers. comm.; Appendix 1: Figs. A5a and b). Pseudemys sp. reported in Foglini \& Salvi, 2017 (ibidem, Supplementary material, Fig. S3) were identified as river cooter Pseudemys concinna (Le Conte 1830) after pictures review.

Unfortunately, the knowledge of the non-native turtle community in the Grugnotorto Villoresi Park is scarcer than in the previously cited area and no specific studies are available. Along with the pervasive presence of $T$. scripta subspecies and hybrids, the following species were reported for the park. In the Parco Lago Nord were found: P. nelsoni and P. concinna (Appendix 1: Figs. A6a and b) also with juveniles (Appendix 1: Figs. A7a and b), Mississippi map turtle G. p. pseudogeographica (Gray 1831 ) and Northern false map turtle G. p. kohnii adults (Appendix 1: Figs. A8a and b) and juveniles (Appendix 1: Fig. A9), Ouachita map turtles Graptemys ouachitensis (one hatchling, 7 July 2019; Appendix 1: Fig. A10), 
spiny softshell turtle Apalone spinifera (LeSueur 1827) (one individual, 19 May 2018; Appendix 1: Fig. A11), M. sinensis (one individual, 18 September 2020; Appendix 1: Fig. A12). Into the Sant'Eusebio protected area the only other species hosted apart from T. scripta is P. concinna (two individuals; Appendix 1: Fig. A13).

\section{DISCUSSION}

The global introduction of non-native amphibians and reptiles has increased exponentially through the past 150 years, and the number of turtle introductions is greater than that of the other taxa altogether (Kraus, 2009). Apart from $T$. scripta, which is already known to be highly invasive, Masin et al. (2014) identified six species with high invasive potential: A. spinifera, Pseudemys floridana (Le Conte 1830), Kinosternon baurii (Garman 1891), Sternotherus odoratus (Latreille in Sonnini \& Latreille 1801), P. subrufa and Pelodiscus sinensis (Wiegmann 1835). In a similar way, according to Kopecký et al. (2013), C. serpentina, $A$. spinifera, $S$. odoratus and $P$. subrufa have the highest rankings of establishment risk.

According to these indications, species that could turn into a major management problem for each of the investigated areas were classified on the basis of their status into the two parks. In both parks, the greatest risk is currently represented by $T$. scripta subspecies and hybrids, present with viable populations and in large numbers (see Foglini \& Salvi, 2017 for Parco Nord Milano).

The genus Pseudemys can be ranked as second: its presence with few big animals in the Parco Nord Milano could be of least concern, but the great number hosted in the Parco Grugnotorto Villoresi (in the Parco Lago Nord) could become a serious problem, given also the presence of small-sized individuals that could represent a first signal of feral reproduction. Although this event in Europe is not widely investigated, reports of $P$. concinna reproduction in Portugal and the observation of hatchlings in Spain (Alves et al., 2013) reinforce the suspicion that this genus may breed into the wild also in Italy.

The two G. pseudogeographica subspecies can be ranked at the third place. They are not listed in Kopecky et al. (2013) nor in Masin et al. (2014), but they are present in both parks with adults of different growing stage. The population hosted in the Parco Lago Nord of the Parco Grugnotorto Villoresi is quite numerous, and it is hard to say if the few juveniles sighted were released pets or if they were locally born. Moreover, in the Parco Nord Milano a nest-digging G. p. kohnii female was reported by Ferri et al. (2019), followed two days later by a similar report concerning one G. pseudogeographica female in the Bresso Lakes (5 July 2018: Gelso, pers. comm.; Appendix 1: Figs. A14a and b). Due to other spawning and hatching events observed in Italy (Ferri et al., 2019), a higher level of attention around this species is desirable. Concerning the genera Pseudemys and Graptemys, further studies about feral populations should be encouraged because their ecology, reproduction and impact outside their native range have rarely been investigated (Alves et al., 2013; Masin et al., 2014).
Concerning G. ouachitensis and M. sinensis, only few individuals were found, although other $M$. sinensis observations are known for different Italian locations (Panzeri et al., 2014).

A. spinifera, P. subrufa and $S$. carinatus were found only as isolated individuals. For this reason, they could be considered more a curiosity than a threat. On the other hand, some genera (e.g. Apalone, Sternotherus, Kinosternon) show a low or even negligible detection probability during visual surveys (Armstrong, 2016) and their occurrence could thus be underestimated. However, as single introductions and early stages of invasion are usually only discovered when individuals have become abundant enough to be easily seen by casual observers (Crooks, 2005), attention must remain high. Lastly, not only non-native species could be victims of irresponsible owners, as demonstrated by the European pond turtle Emys orbicularis (L., 1758) sighted only twice in the Educational area in Parco Nord Milano, probably escaped or released.

Alien turtle occurrence in Mediterranean wetlands represents both a direct and an indirect threat for many native species (Lindsay et al., 2013). However, this silent invasion of artificial water bodies is often considered of minor importance because they typically host poor biological assemblages that do not include native species of conservation concern (Goertzen \& Suhling, 2013; Noble and Hassall, 2015). Nevertheless, the situation in the Parco Nord Milano confirms the role of some urban wetlands in hosting relict or isolated populations of native species of ecological interest (Chovanec, 1994; Vignoli et al., 2009): the park was in fact designated as an important location for the herpetofauna (A.R.E - Area di Rilevanza Erpetologica, ITA036LOM006) thanks to the presence of a relevant breeding population of the Balearic green toad Bufotes balearicus (Boettger, 1880) and small residual populations of the smooth newt Lissotriton vulgaris (L., 1758) (Casale et al., 2012). Even if the Balearic green toad does not share the habitat with the turtles, the smooth newt populations live in ponds and ditches greatly exposed to turtle immigration and/or release. In these water bodies, it is strongly recommended to increase surveillance efforts in order to avoid any release of turtles, and to promptly follow up detection with removal. This is all the more recommended as the wetlands in both parks are home to an interesting community of odonates (Foglini, 2016).

A focal point of this study is the early warning against invasive alien species (Genovesi et al., 2010). In the study area, without a scheduled monitoring program, the arrival of a new non-native turtle species is often detected by chance thanks to the visitors' photographs (for mammals, see Mori et al., 2017) or occasional reports about the presence of an individual visually perceived as strange or different from the usual turtles. On the one hand, this is a sign that alien turtles are a popular topic, but it emphasises the need to involve professionals to properly identify the invasive species. Without an accurate species identification, any decision aimed to the management of a potential invasion, even if rapid, could come with irremediable delay (Maistrello et al., 2016). 


\section{Acknowledgments}

I wish to thank Marco Siliprandi, ranger of the Parco Nord Milano, and all the people who shared their sightings and photographs. In particular, I am all the most grateful to Maria Rita Gelso, Anna and Maurizio Ghislandi and Riccardo Tucci. My grateful thought goes also to Mirko Galuppi, for his helpful hints about some individual identifications. I thank Giorgio Chiozzi for his comments, which improved a first version of the manuscript. Many thanks also to Francesco Ficetola and an anonymous referee, for their valuable aid.

\section{REFERENCES}

Alves A., Martínez-Silvestre A., Alves A. \& Martins J. J., 2013 - Are the invasive species Trachemys scripta and Pseudemys concinna able to reproduce in the northern coast of Portugal? Symposium on Freshwater Turtles Conservation, Oporto.

Armstrong D. P., 2016 - Using reference sites to account for detection probability in occupancy surveys for freshwater turtles. Herpetological Conservation and Biology, 11: 505-518.

Bogliani G., Agapito Ludovici A., Arduino S., Brambilla M., Casale F., Crovetto G. M., Falco R., Siccardi P. \& Trivellini G., 2007 - Aree prioritarie per la biodiversità nella Pianura Padana lombarda. Fondazione Lombardia per l'Ambiente e Regione Lombardia, Milano.

Bringsøe H., 2006 - NOBANIS. Invasive Alien Species Fact Sheet. Trachemys scripta. From: Online Database of the North European and Baltic Network on Invasive Alien Species. <www.nobanis. org $>$ (accessed 22 February 2021).

Burgin S., 2006 - Confirmation of an established population of exotic turtles in urban Sydney. Australian Zoologist, 33: 379-384.

Cadi A. \& Joly P., 2000 - The introduction of the slider turtle (Trachemys scripta elegans) in Europe: competition for basking sites with the European pond turtle (Emys orbicularis). Chelonii, 2: 95-97.

Casale F., Bergero V., Brambilla M., Campana F., Decarli M. L., Falco R., Gini R., Redondi A., Siliprandi M., Tucci R., Crovetto G. M. \& Bogliani G., 2012 - Atlante della biodiversità nelle aree protette del Nord Milanese. Fondazione Lombardia per l'Ambiente, Milano.

Chovanec A., 1994 - Man-made wetlands in urban recreational areas. A habitat for endangered species? Landscape and Urban Planning, 29: 43-54.

Çiçek K. \& Ayaz D., 2015 - Does the red-eared slider (Trachemys scripta elegans) breed in Turkey? Hyla, 1: 4-10.

Conner C. A., Douthitt B. A. \& Ryan T. J., 2005 - Descriptive ecology of a turtle assemblage in an urban landscape. American Midland Naturalist, 153: 426-435.

Crescente A., Sperone E., Paolillo G., Bernabò I., Brunelli E. \& Tripepi S., 2014 - Nesting ecology of the exotic Trachemys scripta elegans in an area of Southern Italy (Angitola Lake, Calabria). AmphibiaReptilia, 35: 366-370.

Crooks J. A., 2005 - Lag times and exotic species: the ecology and management of biological invasions in slow-motion. Ecoscience, 12: 316-329.

De Lathouder R., Jones D. N. \& Balcombe S. R., 2009 - Assessing the abundance of freshwater turtles in an Australian urban landscape. Urban Ecosystem, 12: 215-231.

European Commission, 1997 - Council Regulation (EC) No 338/97 of 9 December 1996 on the protection of species of wild fauna and flora by regulating trade therein. Official Journal of the European Union, 40: 1-69.

European Commission, 2001 - Commission Regulation (EC) No 2087/2001 of 24 October 2001 suspending the introduction into the Community of specimens of certain species of wild fauna and flora. Official Journal of the European Union, 44: 23-38.

European Commission, 2014 - Regulation (EU) No 1143/2014 of the European Parliament and of the Council of 22 October 2014 on the prevention and management of the introduction and spread of invasive alien species. Official Journal of the European Union, 57: $35-55$.
Ferri V., Soccini C. \& Santoro R., 2019 - Prima segnalazione di riproduzione di Graptemys pseudogeographica kohni (Baur, 1890) in ambient naturali e urbani italiani (Chelonia, Emydidae). II Congresso Nazionale Testuggini e Tartarughe, 11-13 Aprile 2019 (Albenga, SV).

Foglini C., 2016 - Odonata next-door: an updated check-list of two parks in the Northern Milan outskirt (Lombardy, Italy). Natural History Sciences, 3 (2): 35-40.

Foglini C. \& Salvi R., 2017 - Non-native turtles in a peri-urban park in northern Milan (Lombardy, Italy): species diversity and population structure. Acta Herpetologica, 12 (2): 151-156.

Genovesi P., Scalera R., Brunel S., Roy D. B. \& Solarz W., 2010 Towards an early warning and information system for invasive alien species (IAS) threatening biodiversity in Europe. European Environmental Agency Technical report, Copenhagen, Denmark, 5 (2010).

Goertzen D. \& Suhling F., 2013 - Promoting dragonfly diversity in cities: major determinants and implications for urban pond design. Journal of Insect Conservation, 17: 399-409.

Kopecký O., Kalous L. \& Patoka J., 2013 - Establishment risk from pet-trade freshwater turtles in the European Union. Knowledge and Management of Aquatic Ecosystems, 410, 02.

Kraus F., 2009 - Alien Reptiles and Amphibians: a Scientific Compendium and Analysis. Springer, New York.

Lindsay M. K., Zhang Y., Forstner M. R. J. \& Hahn D., 2013 - Effects of the freshwater turtle Trachemys scripta elegans on ecosystem functioning: an approach in experimental ponds. Amphibia-Reptilia, 34: 75-84.

Maistrello L., Dioli P., Bariselli M., Mazzoli G. L. \& Giacalone-Forini I., 2016 - Citizen science and early detection of invasive species: phenology of first occurrences of Halyomorpha halys in Southern Europe. Biological Invasion, 18: 3109-3116.

Masin S., Bonardi A., Padoa-Schioppa E., Bottoni E. \& Ficetola G. F., 2014 - Risk of invasion by frequently traded freshwater turtles. Biological Invasion, 16: 217-231.

Mori E., Baeri A., Sforzi A., Vitale A. \& Galimberti A., 2017 - From accidental citizen-science observations to genetic confirmation: how to spot new hidden invaders. Hystrix, the Italian Journal of Mammalogy, 28 (2): 284-287.

Noble A. \& Hassall C., 2015 - Poor ecological quality of urban ponds in northern England: causes and consequences. Urban Ecosystems, 18 (2): 649-662.

Panzeri M., Mori E., Mazza G. \& Menchetti M., 2014 - Records of introduced stripe-necked terrapins (Mauremys species) in Italy. Acta Herpetologica, 9 (2): 227-230.

Piovano S. \& Giacoma C., 1999 - Censimento di Trachemys scripta elegans presente in un parco di Torino. Rivista di Idrobiologia, 88: 499-508.

Rhodin A. G. J., Iverson J. B., Bour R., Fritz U., Georges A., Shaffer H. B. \& van Dijk P. P., 2017 - Turtles of the World: annotated checklist and atlas of taxonomy, synonymy, distribution, and conservation status ( $8^{\text {th }}$ ed.). In: Conservation biology of freshwater turtles and tortoises: a compilation project of the IUCN/SSC Tortoise and Freshwater Turtle Specialist Group. Rhodin A. G. J., Iverson J. B., van Dijk P. P., Saumure R. A., Buhlmann K. A., Pritchard P. C. H. \& Mittermeier R. A. (eds.). Chelonian Research Monographs, 7: 1-292.

Seidel M. E. \& Ernst C. H., 1996 - Pseudemys. Catalogue of American amphibians and reptiles, 625: 1-7.

van Ham C., Genovesi P. \& Scalera R., 2013 - Invasive Alien Species: The Urban Dimension. Case studies on strengthening local action in Europe. IUCN European Union Representative Office, Brussels.

Vignoli L., Mocaer I., Luiselli L. \& Bologna M. A., 2009 - Can a large metropolis sustain complex herpetofauna communities? An analysis of the suitability of green space fragments in Rome. Animal Conservation, 12: 456-466.

Vogt R. C., 1993 - Systematics of the false map turtles (Graptemys pseudogeographica complex: Reptilia, Testudines, Emydidae). Annals of Carnegie Museum 62 (1): 1-46.

\section{APPENDIX 1}

May be found online for this article. 